\title{
Evaluation of Malaysian Primary English Language Textbooks
}

\author{
Nur Atiqah binti Md Sungif \\ University Putra Malaysia \\ Dayang Hartijah binti Abang Ahmad (Corresponding author) \\ University Putra Malaysia \\ E-mail: tjay88_ok@yahoo.com \\ Jayakaran Mukundan \\ University Putra Malaysia
}

Doi:10.7575/aiac.alls.v.5n.5p.5

Received: 09/06/2014

URL: http://dx.doi.org/10.7575/aiac.alls.v.5n.5p.5

Accepted: 10/08/2014

\begin{abstract}
The purpose of this study is to evaluate the contents of in-use Year 5 and Year 6 textbooks in Malaysian primary schools in exploring the strengths and weaknesses of the textbooks. Does it really apply all the methods and suitability for the pupils? It is also aim to study whether the textbooks fit to all level of pupils' proficiency in English language and whether it giving attention on the pupils' proficiency level in language learning. Sample of the study consists of 32 English teachers chosen randomly from primary schools in Selangor. In this study, the textbook is evaluated in terms of general attributes and learning content categories and evaluation checklists proposed by previous researchers are distributed as instrument used. The findings revealed that the textbook for each year is very highly useful. It is also found that the textbooks are suitable for either for low proficiency or vice versa.
\end{abstract}

Keywords: textbook evaluation, ELT-TEC, checklist, Malaysian teachers

\section{Introduction}

As we know, society and teachers are taking a serious thought when selecting the textbook for student to learning. It is broadly known that a good textbook is essential in English language teaching. Despite of the colourful and attractive picture in the book and the beautiful layout, teachers must look in depth in their content as well. It is a guideline for the teacher to know the suitable text or activity considered the various level of students' proficiency that can use in classroom. According to Hutchinson and Waters, the textbook evaluation is a straightforward, analytical 'matching process: matching needs to available solutions' (Hutchinson and Waters 1987:97).

\subsection{Statement of problem}

Textbook is crucial for any teaching course because it helps teachers and guides them in anyway, but thus the textbook is very useful? Or does it matches the specifications of the syllabus? Are they really interesting to attract students attention in learning? Some teachers might be complaining about the level of the language uses in the textbook or even the content itself, as for them, the content should have some adjustment that suit for their students. These are the questions that always play among the teachers. The need of adaptation and that is why the evaluation on the textbook is needed.

In order to investigate the usefulness and the effectiveness of textbook, the need of evaluating the textbook is fundamental. According to John (2001) "a majority of teachers use textbooks as their principal curriculum guide and source of lessons" (p.32). Textbooks have gigantic influence in classroom learning and teaching, either primary, elementary and secondary classes. It's also took place on how it is being taught. Besides, this evaluation should be done to make sure that the textbook is beneficial for teachers and students. Teacher always want the best for their students nevertheless it will include the usage of teaching materials. The good quality and reliability teaching materials such as textbook will help them to teach the students based on the syllabus and level of proficiency.

With all the concern, the evaluation is essential for them to ensure that the components in the textbook is effective, whether the layout or the language, the activity and also suitability to be used in classroom teaching and learning. The researchers also want to examine whether the textbook is perfectly written and suitable in language teaching and learning class, and also meet the specification in terms of method, syllabus and also pedagogy in teaching and learning, or need some adaptation in it.

\subsection{Research Questions}

There are several questions that the researchers are aware off:

1. How do the teachers evaluate the general attributes of Year 5 and Year 6 textbooks?

2. How do the teachers evaluate learning-teaching content of Year 5 and Year 6 textbooks? 
3. How do the teachers evaluate components in general attributes of Year 5 and Year 6 textbooks?

4. How do the teachers evaluate the main language components of Year 5 and Year 6 textbooks?

\subsection{Significance of the Study}

The study is hopefully able to reveal how determine the teachers in evaluating the effectiveness of the textbook in order to consider the improvement that can be made towards the current in-use textbooks. The study is also expected to be able to help teachers to understand more on the textbook content itself. The result of this study is also hopefully will be beneficial in helping teachers and the educational administration in evaluating the effectiveness of the textbook, in order to improve the textbook in future.

\section{Literature Review}

\subsection{Justification for Textbook Evaluation}

A study on the importance of knowing the process and how to select textbook materials by Angell, DuBravac \& Gonglewski (2008) argued that selecting materials for textbook should be made based on the consideration of the local context that meet the needs of any programme. They also suggested that those responsible for textbook selection may find it helpful to stay abreast of major trends in foreign language pedagogy, teaching methodology, and technological developments. The authors also mentioned that there were possibilities that the profession may be as accustomed to accepting textbooks as complete curricular and instructional roadmaps that they may not examine the materials as rigorously as they should. Based on these statements, the current study is hopefully able to provide path that leads to betterment in producing ELT materials and textbook.

Kirkgoz (2009) and as remarked by Richards (2001) mentioned that good textbooks serve to turn the guidelines in the official government syllabus into a rich source of content. Conversely, textbooks should help teachers in attending the ideas that students already have and to help students gain a better understanding of key concepts and skills. This will help in concept building. Concepts are key building blocks for the structure of knowledge of various academic disciplines. All concepts possess at least four components i.e. attributes, examples, definitions and hierarchical relation (Tennyson \& Park, 1980; in Mahmood, Iqbal, \& Saeed, 2009).

The current study involves the whilst-use evaluation, taken from Tomlinson Model (1999). In Tomlinson's (2003) words, materials evaluation is a procedure that involves measuring the value of a set of learning materials. Thus, in this whilst-use evaluation, the textbooks were measured based on the value of materials whilst using them or whilst observing them being used. It is more objective and reliable than pre-use evaluation and it makes use of measurement rather than prediction in exploring the weaknesses or strengths of the textbooks.

\subsection{Past Research on ESL Textbook Evaluation Studies}

Quality textbook in terms of the attributes and contents can help students grow intellectually and personally. There were a lot of previous studies been made on ELT materials and textbooks evaluation in different levels, namely primary, secondary and tertiary levels around the world. Each study came with different purposes and instruments.

Litz (2005) in her case study evaluated English Firsthand \#2 textbook of EFL programme at Sung Kyun Kwan University Science and Technology Campus which are used by 500 high-beginner students and eight instructors. The results showed that the textbook stood up reasonably well and compatible with the university's language aims despite a few reservations and shortcomings. The students also reported that the textbook was somewhat stimulating and useful for their purposes.

On the other hand, Kirkgoz (2009) found in his study that the three evaluated textbooks which currently used by grade 4 classes in Turkish state primary schools were carefully designed to meet the MNE curriculum goals and objectives which meet the young learners' needs and interests. Both teachers and students positively responded toward the usage of those textbooks, in the aspects of the layout and design, language content, methodology, subject content and skills provided in the textbooks. The students also unanimously agreed that all the three textbooks were colourful, wellillustrated with pictures with interesting characters, drawings and appropriate for their proficiency levels.

In accordance with this, Yuasa (2010) evaluated English textbooks currently used in Japan and Korea in terms of the focus materials in textbooks by both countries. Based on his study, the findings showed that textbooks in both countries were contrived to make learners interested in English by taking up interesting topics and using attractive illustrations and photographs. The only difference was Koreans aim for learning English is to express themselves and exchange ideas, meanwhile Japanese using English to arouse their interest in foreign culture and society to foster their motivations to communicate in the language. The textbooks evaluation both countries underpinned the current study to study the importance of textbook evaluation in our local context in order to see the appropriateness of our current textbooks used in Malaysian primary schools.

A recent study by Mukundan \& Rezvani Kalajahi (2013) evaluated English textbooks used by Year 1 to Year 6 and Form 1 to Form 5 students in Melaka state, in terms of general attributes of the textbooks and the teaching-learning content. In this study, the findings showed that Year 1 to Year 6 teachers responded that the current textbooks were highly useful, meanwhile Form 1 to Form 5 teachers reported that the textbooks were moderately useful for the students in both general attributes of the textbooks and the teaching-learning content in the textbooks.

Davari, Iranmehr \& Erfani (2013) in their recent study evaluated four ESP textbooks developed and published by PayamNour University (PNU), as the second ESP textbooks developer in Iranian academic setting. The findings revealed that the textbooks contained low face validity, lack of materials reviewing and updating, and also ineffective and traditional exercises and drills which unattractive for the students. Not only that, the findings also showed that the 
textbooks contained a misconception of ESP, especially for not serving purposes for which the course was designed. The authors summed up by stating there was a mismatch between theory and practice, as the lack of consistency in the textbooks in the aspects of theory and practice. As for suggestions, the authors stated that it is better to do thorough and comprehensive needs analysis in order to fulfil the objectives of ESP instruction and essentially revising and updating the books.

It can be seen that the current study also focused the reflections on the effectiveness of the textbooks in-use in Malaysian state primary schools. Thus, this study might be able to contribute to a large extent towards the effectiveness and cohesiveness of materials in the current textbook for primary schools. Since this study is limited to state primary schools in Malaysia, it is hope that this study can be improved further in the aspects of population and scope of the study. In the following, the study initially described from which the paper is drawn and explain how the data was collected and analysed.

\section{Methodology}

\subsection{Sample of the study}

A total number of 32 primary schools teachers took part in this study, consisted of 9 male teachers $(28.1 \%)$ and 23 female teachers $(71.9 \%)$ teaching Year 5 and Year 6 in primary schools in Selangor state. It is shown in table 1 as below.

\begin{tabular}{|c|c|c|c|c|c|}
\hline & & Frequency & Percent & $\begin{array}{c}\text { Valid } \\
\text { Percent }\end{array}$ & $\begin{array}{c}\text { Cumulative } \\
\text { Percent }\end{array}$ \\
\hline \multirow[t]{3}{*}{ Valid } & Male & 9 & 28.1 & 28.1 & 28.1 \\
\hline & Female & 23 & 71.9 & 71.9 & 100.0 \\
\hline & Total & 32 & 100.0 & 100.0 & \\
\hline
\end{tabular}

\subsection{Data Collection Method}

In this study, a checklist proposed by Mukundan and Nimchisalem (2011) was used as the instrument by researchers. The checklist is called the English Language Teaching Textbook Evaluation Checklist (ELT-TEC), which comprised two main sections. The first section is the textbook general attributes, consisted questions from the aspects of syllabus and curriculum, methodology, suitability to learners, physical and utilitarian attributes and efficient layout of materials. Another section namely learning-teaching content consisted questions from the aspects of general content of the textbook, listening, speaking, reading, writing, vocabulary, grammar, pronunciation and exercises.

Likert scale is used as the rating system in this study, $0=$ NEVER TRUE, $1=$ RARELY TRUE, 2=SOMETIMES TRUE, $3=$ OFTEN TRUE, 4=ALWAYS TRUE and NA=NOT APPLICABLE. On the other hand, the range of the score interpretation guide for the textbook evaluation is as below:

Table 2. Scores Interpretation Guide

\begin{tabular}{ccc}
\hline Level & Range & Interpretation \\
\hline 0 & $0.00-0.80$ & Negligible usefulness \\
1 & $0.81-1.60$ & Low usefulness \\
2 & $1.61-2.80$ & Moderate usefulness \\
3 & $2.81-3.60$ & High usefulness \\
4 & $3.61-4.00$ & Very high usefulness \\
\hline
\end{tabular}

\subsection{The Validity of the Instrument}

The English language Teaching Textbook Evaluation Checklist (ELT-TEC) has been tested for its validity by Mukundan, Nimehchisalem, \& Hajimohammadi (2011). In their study, a group of evaluators ( $\mathrm{n}=82$ ) who used the checklist to assess a textbook, proven their satisfaction in using ELT-TEC, which was about (72-95\%). Besides, the instrument has also verified to be economical. The Standard of evaluators access to ELT-TEC is took mostly around 9.5 minutes to access the textbook.

\subsection{The Reliability of the Instrument}

The checklist reliability has also been tested by Mukundan, Nimehchisalem, \& Hajimohammadi (2011) with an interrater reliability test where it shown an acceptable reliability coefficients $(r=.962)$. In addition, for the present study, the internal reliability was also calculated. Table 3 presents the Cronbach reliability statistics for ELT-TEC. The reliability is considerably high $(\mathrm{r}=.962)$. 
Table 3. Reliability Statistics

\begin{tabular}{cc}
\hline Cronbach's Alpha & N of items \\
\hline .962 & 39 \\
\hline
\end{tabular}

\section{Findings and Discussions}

4.1 General attributes in Year 5 and Year 6 textbooks.

\begin{tabular}{ccc}
\hline Year & Mean & SD \\
\hline Year 5 & 3.99 & 0.28 \\
\hline Year 6 & 4.50 & 2.03 \\
\hline
\end{tabular}

Generally, findings revealed that all Year 5 and Year 6 teachers agreed that the textbooks they are currently used are very highly useful in terms of the general attributes. According to the table, the mean for Year 6 textbook is slightly higher than Year 5 textbook. This finding is parallel to Kirkgoz (2009) in his study of Turkish primary school textbooks, where he revealed that the textbooks were carefully designed to meet the MNE curriculum goals and objectives which meet the young learners' needs and interests. Both previous and current studies also positively responded toward the usage of the textbooks in terms of the layout and design, language content and methodology in evaluated textbooks.

4.2 Learning-teaching content in Year 5 and Year 6 textbooks

\begin{tabular}{ccc}
\hline Year & Mean & SD \\
\hline Year 5 & 3.83 & 0.33 \\
\hline Year 6 & 4.14 & 0.44 \\
\hline
\end{tabular}

For the learning-teaching content of the textbooks, it is also reported that both Year 5 and Year 6 textbooks are very highly useful for the teachers in terms of learning-teaching content with mean score of $(\mathrm{M}=3.83, \mathrm{SD}=0.33)$ for Year 5 textbook and $(\mathrm{M}=4.14, \mathrm{SD}=0.44)$ for Year 6 textbook. Again, the mean score for Year 6 textbook is higher than Year 5 textbook. This finding is slightly distinguished with a recent study by Mukundan \& Kalajahi (2013), where they found that Year 1 to Year 6 teachers responded that the current textbooks were highly useful.

4.3 Components in general attributes in Year 5 and Year 6 textbooks

\begin{tabular}{l|cc|cc}
\hline \multirow{2}{*}{\multicolumn{1}{c|}{ Components }} & \multicolumn{3}{c|}{ Year 5 } & \multicolumn{2}{c}{ Year 6 } \\
\cline { 2 - 5 } & Mean & SD & Mean & SD \\
\hline Syllabus and curriculum & 4.16 & 0.44 & 4.34 & 0.57 \\
\hline Methodology & 3.75 & 0.32 & 3.88 & 0.62 \\
\hline Suitability & 3.75 & 0.41 & 4.16 & 0.57 \\
\hline Physical and utilitarian attributes & 4.33 & 0.34 & 4.33 & 0.34 \\
\hline Efficient layout & 3.86 & 0.53 & 3.67 & 0.73 \\
\hline
\end{tabular}

Specifically, for components in general attributes in Year 5 textbook, the highest mean score $(\mathrm{M}=4.33, \mathrm{SD}=0.34)$ was reported for from the physical and utilitarian attributes, comprised of the efficient use of text and visuals and also attractive layout. Meanwhile the lowest mean scores $(\mathrm{M}=3.75, \mathrm{SD}=0.32 ; \mathrm{M}=3.75, \mathrm{SD}=0.41)$ were reported for from methodology and suitability components. This finding is parallel to Litz (2005) in her case study of English Firsthand \#2 textbook used in EFL programme at Sung Kyun Kwan University, where she found that the textbook was stimulating and useful for the students' purposes.

For Year 6 textbook, the highest mean score $(\mathrm{M}=4.34, \mathrm{SD}=0.57)$ was reported for from the syllabus and curriculum component, whereas the lowest mean score $(\mathrm{M}=3.67, \mathrm{SD}=0.73)$ was reported for from the efficient layout attributes.

4.4 The six language components in Year 5 and Year 6 textbooks

\begin{tabular}{lcccc}
\hline \multirow{2}{*}{ Language Components } & \multicolumn{2}{c}{ Year 5 } & \multicolumn{2}{c}{ Year 6 } \\
\cline { 2 - 5 } & Mean & SD & Mean & SD \\
\hline Listening & 3.79 & 0.44 & 3.98 & 0.43 \\
\hline Speaking & 3.78 & 0.52 & 4.00 & 0.73 \\
\hline Reading & 3.73 & 0.39 & 3.96 & 0.56 \\
\hline Writing & 3.59 & 0.58 & 4.03 & 0.56 \\
\hline Vocabulary & 3.72 & 0.49 & 4.22 & 0.66 \\
\hline Grammar & 3.94 & 0.40 & 4.31 & 0.48 \\
\hline
\end{tabular}


Finally, for the six language components in Year 5 textbook, the highest mean score $(\mathrm{M}=3.94, \mathrm{SD}=0.40)$ was reported for the grammar component. Meanwhile the lowest mean score $(\mathrm{M}=3.59, \mathrm{SD}=0.58)$ was reported for the writing components. Meanwhile for Year 6 textbook, the highest mean score $(\mathrm{M}=4.31, \mathrm{SD}=0.48)$ was also reported for the grammar component, whereas the lowest mean score $(\mathrm{M}=3.96, \mathrm{SD}=0.56)$ was reported for the listening component.

\section{Conclusion and Recommendation}

As a conclusion, it can be stated that both Year 5 and Year 6 textbooks that are currently used in primary schools in Selangor are very highly beneficial for the pupils, in terms of the general attributes and learning-teaching content of the textbooks. However, the finding cannot be generalised to all Malaysian primary schools as the population is referred to schools Selangor state only. Nevertheless, the finding still can be used as a reference for improving the current textbooks and also for future research literature review.

It is recommended that further studies in future to be done by evaluating textbook in different components in order to produce a holistic examination and evaluation of educational textbooks used in Malaysian schools. It is also suggested that further studies to be done in using different approaches of evaluation such as pre-use or post-use evaluations.

\section{References}

Angell, J., DuBravac, S., \& Gonglewski, M. (2008). Thinking Globally, Acting Locally: Selecting Textbooks for College-Level Language Programs. Foreign Language Annals, 41(3), 562-573.

Davari, H., Iranmehr, A., \& Erfani, S. (2013). A Critical Evaluation of PNU ESP Textbooks. Journal Of Language Teaching \& Research, 4(4), 813-823. doi:10.4304/jltr.4.4.813-823

Hutchinson, T., \& Waters, A. (1987). English for Specific Purposes: A Learning0Centered Approach. Cambridge: Cambridge University Press

John, St. M. (2001). The Status of High School Science Programmes and Curricular 'Decision-Making. Inverness, CA: Inverness Research Associates.

Mahmood, K., Iqbal, M. Z., \& Saeed, M. (2009). Textbook Evaluation through Quality Indicator: The Case of Pakistan. Education and Research December 2009, Vol. 31, No. 2 pp 1-27

Kırkgöz, Y. (2009). Evaluating the English textbooks for Young Learners of English at Turkish Primary Education. Procedia-Social and Behavioral Sciences, 1(1), 79-83.

Litz, D.R. (2005). Textbook evaluation and ELT management: A South Korean case study. Asian EFL journal, 6(4).

Mukundan, J., \& Rezvani Kalajahi, S. A. (2013). Evaluation of Malaysian English Language Teaching Textbooks. International Journal of Education \& Literacy Studies, Vol. 1, No. 1 pp 38-43

Mukundan, J., Nimehchisalem, V., \& Hajimohammadi, R. (2011). Developing an English Language Textbook Evaluation Checklist: A Focus Group Study. International Journal of Humanities Developing an English Language, 1(12), 100-105.

Tomlinson, B. (2003). Materials Evaluation, in B. Tomlinson, Developing Materials for Language Teaching (15-36), London: Continuum.

Yuasa, K. (2010). English Textbooks in Japan and Korea. Journal of Pan-Pacific Association of Applied Linguistics, 14(1), 147-158. 